\title{
Proposed Criteria for Early Detection of Leprotic Arthropathy
}

\author{
Mohamad I Hanafy ${ }^{1}$, ${ }^{*}$ Hesham Hamoud ${ }^{1}$, Abdulaziz A Mustafa ${ }^{1}$ and Gamal A elkheshen ${ }^{2}$ \\ ${ }^{1}$ Department of Rheumatology, Al-Azhar University, Egypt \\ ${ }^{2}$ Department of Rheumatology Clinical Pathology, Al-Azhar University, Egypt
}

Submission: April 23, 2017; Published: May 24, 2017

*Corresponding author: Hesham Hamoud, 24 Mohamad Tawfik Diab, Makram Ebid Nasr City, Department of Rheumatology, Cairo, Egypt, Tel: 201100000129; Email: hamoud.hesham@yahoo.com

Abstract

Leprosy is a chronic mycobacterial disease infectious in some cases primarily affecting the peripheral nervous system and secondarily involving skin specially the melanocyte and certain other tissues [1]. During the past decade, serological tests for detection of antimycobacterium leprae antibodies have been developed, among them, the enzyme-linked immunosorbent assay (ELIZA) using the purified phenolic glycolipid-I (PGL-I) from the cell wall as a mycobacterium leprae specific antigen has proved to be potentially useful for the serological study of leprosy patients, household contacts and normal individuals due to its simplicity, sensitivity as well as its capability of handling large numbers of sera simultaneously [2].

Objectives: was the early prediction and diagnosis of leprotic arthropathy among Egyptian leprotic patients \& their household contacts.

Patients and methods: Sixty leprotic patients with their ninety- two household contacts who were suffering from musculoskeletal disorders in addition to sixty healthy control subjects were included in this study. full clinical examination, radiological examination , Routine laboratory investigations and serum anti-phenolic glycolipid I (Anti-PGL) which is a unique constituent in the inner layer of the cell wall of mycobacterium leprae Cho et al. [3].

Results: wrist, distal interphalangeal (DIP) and metacarpophalangeal (MCP) were highly significantly involved in cases than in other groups $(\mathrm{P}<0.001)$. Knees and metatarsophalangeal (MTP) were more prevalent among cases than in other groups with a high significant difference $(P<0.001)$. The mean serum level of AGLI (IgM) antibodies was more among cases and their household contacts than in control groups with a very high significant difference $(p<0.0001)$.The mean serum level of APGLI $(A$ IgG) antibodies was significantly higher among cases and their household contacts than in controls with a very high significant difference $\mathrm{P}<0.0001$

Conclusion: from the previous results we can suggest the following criteria for the early prediction and diagnosis of leprotic arthropathy which might be:

I. Positive APGL-I (IgM > 0.085, IgG > 0.0180).

II. High enthesopathy index $>10$.

III. Skin manifestations (hypo or hyper pigmented patches).

IV. Loss of hair especially eye brows.

V. Arthralgia and / or arthritis in attacks: RA like, or monoarticular.

VI. Peripheral nerve thickening

VII. Radiological changes wither early as: -
A. Soft tissue swelling
B. Osteoporosis
C. Acroosteolysis

Or late as:

i. joint space narrowing

ii. Acroosteolysis

iii.Arthritis multilans

iv. Deformities and ankylosis 


\section{Introduction}

Leprosy is a chronic mycobacterial disease infectious in some cases, primarily affecting the peripheral nervous system and secondarily involving skin specially the melanocyte and certain other tissues [1]. Road, et al. [4], stated that, even in countries with developed health services leprosy often diagnosed only in advanced stages of the disease due to;

I. In most societies, leprosy is not endemic and occurs only as an imported disease of minor public health importance.

II. Little attention is being paid to teaching leprosy in medical schools. Moreover, chapters of leprosy in general textbooks are not always updated.

III. Traditional fear is still common, the patients are often reluctant to expose themselves as leprotic patients because the fear of restrictive measure. Considerable attention has been directed to the dermal, neural and osseous complications of leprosy [5]. Reports of joint involvement in leprosy have been published since the 1960s [6,7] but the main aspect of interest in this work was to study the joint involvement in leprosy patients not in reaction since the arthritis in Lepra reaction type 2 is well known [8] (Figure 1).

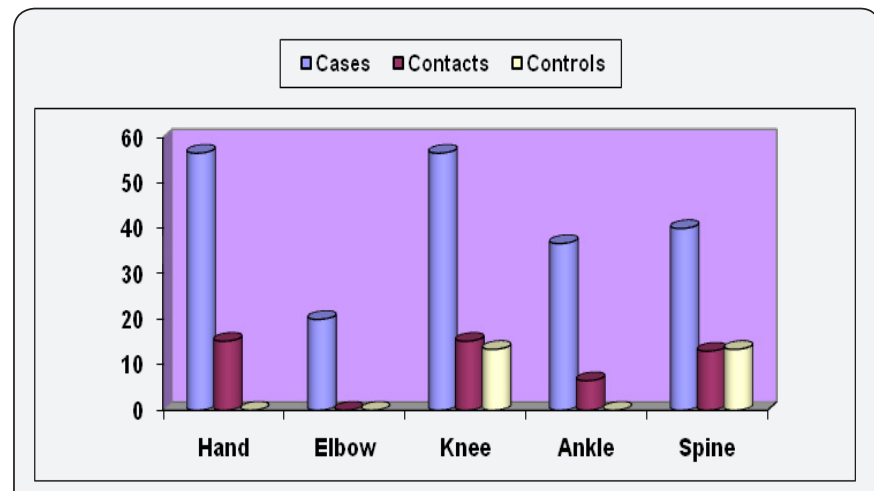

Figure 1: Joints.

$0=$ Normal

$\mathrm{I}=$ Soft tissue swelling

II = Juxt-articular op \& j. S.N.

III = Erosions and j. S.N.

IV = Deformity \& Ankylosis

$\mathrm{V}=$ Charcots joint

\section{Patients and Methods}

Sixty leprotic patients with their ninety two household contacts suffering from musculoskeletal disorders in addition to sixty control subjects were included in this study. All patients and their household contacts were selected from Abou-Zaabal, Al-Safieh, Masowd villages, (Al Kalyobia Governorate.) .The patients were 42 8 AND $18+$, their ages ranged from $15-60$ years ; mean $(44.83 \pm$ 4.70). The household contacts were $5636 \%$, their age ranged from $12-58$ years; mean $(32.03 \pm 11.99)$ with no family history of leprosy and no known exposure to leprosy, they were randomly chosen from the medical and nurse staff members. The patients selected were already diagnosed with leprosy, but not classified into any type of leprosy as the classification requires pathological examination and the conversion to any other type occurs without any rule. All patients, their household contacts and the control group were submitted to Careful family history, full clinical examination, radiological examination, routine laboratory Investigations and serum anti-phenolic glycolipid I (Anti-PGL) which is a unique constituent in the inner layer of mycobacterium leprae cell wall Cho, et al. [3]. The small and large joints were examined from all aspects according to Spread-severity index [9]. Ritchie index [10] was used to assess joint tenderness. Radiological examination: The scoring system for radiographs was done according to Larsen, et al. [11] (Figure 2).

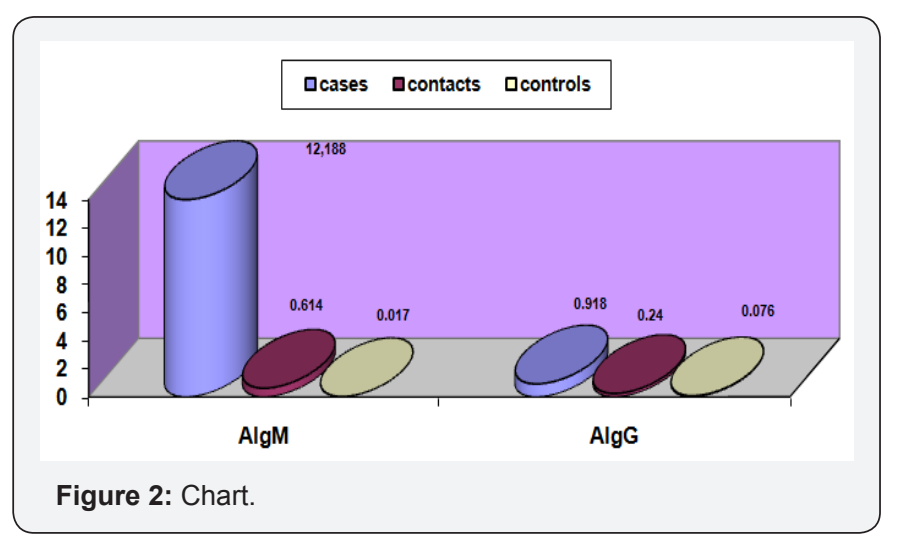

Serum samples: $5 \mathrm{ml}$ of blood were withdrawn by clean syringe and transferred to clean dry sterilized tube, which was hold in vertical position for one hour. The tube was centrifuged for 15 minutes to separate the serum. The serum was taken to another clean dry sterilized tube capped and stored at $-70{ }^{\circ} \mathrm{C}$ until used. Assessment of anti-PGL-1 antibody in the serum by using the ELISA method described by Cho, et al. [3] with minimal modifications Kazda, et al. [12]. The semi-synthetic antigen (Neoglycoprotein NDO-BSA) was kindly provided by Dr. R.J.W. Rees, National institute for medical research, London. It was dissolved in carbonate coating buffer $(9.6 \mathrm{pH})$ by sonication for 10 seconds and adjusted to final concentration of $2 \mathrm{ug} / 1 \mathrm{ml}$ in the same buffer.

\section{Results}

Table 1 showed that there was no significant difference in spread severity index between cases, contacts and the control group regarding the tempromandibular, glenohumeral and elbow, hip and subtalar joints where $(\mathrm{P}>0.05)$. However the acromioclavicular and ankle joints were significantly more involved among cases than the other groups $(\mathrm{P}<0.05)$. The wrist, distal interphalangeal (DIP), metacarpophalangeal (MCP) and the proximal interphalangeal (PIP), knees, and Metatarsophalangeal (MTP) joints were highly significantly involved in cases than the other groups $(\mathrm{P}<0.001)$. 
Table 1: The percentage distribution of joint involvement for all of the Studied groups according to ss. Index (Balakrishman and Mehra) [30].

\begin{tabular}{|c|c|c|c|c|c|c|c|c|}
\hline & & \multicolumn{2}{|c|}{ Cases } & \multicolumn{2}{|c|}{ Contacts } & \multicolumn{2}{|c|}{ Controls } & \\
\hline & & No. & $\%$ & No. & $\%$ & No. & $\%$ & \\
\hline \multirow{2}{*}{ TMJ } & 0 & 54 & 90 & 92 & 100 & 60 & 100 & \multirow{2}{*}{$\mathrm{p}>0.05$} \\
\hline & I & 6 & 10 & 0 & 0 & 0 & 0 & \\
\hline \multirow{3}{*}{ Cer. spine } & 0 & 38 & 63.3 & 74 & 80.4 & 52 & 86.7 & \multirow{3}{*}{$P>0.05$} \\
\hline & I & 22 & 36.7 & 18 & 19.6 & 8 & 13.3 & \\
\hline & II & 0 & 0 & 0 & 0 & 0 & 0 & \\
\hline \multirow{3}{*}{ St. Clav. } & 0 & 52 & 86.6 & 88 & 95.7 & 60 & 100 & \multirow{3}{*}{$\mathrm{p}>0.05$} \\
\hline & I & 4 & 6.7 & 4 & 4.3 & 0 & 0 & \\
\hline & II & 4 & 6.7 & 0 & 0 & 0 & 0 & \\
\hline \multirow{2}{*}{ ACJ } & 0 & 54 & 90 & 92 & 100 & 60 & 100 & \multirow{2}{*}{$\mathrm{p}<0.05$} \\
\hline & I & 6 & 10 & 0 & 0 & 0 & 0 & \\
\hline \multirow{3}{*}{ GHJ } & 0 & 56 & 93.4 & 92 & 100 & 60 & 100 & \multirow{3}{*}{$P>0.05$} \\
\hline & I & 2 & 3.3 & 0 & 0 & 0 & 0 & \\
\hline & II & 2 & 3.3 & 0 & 0 & 0 & 0 & \\
\hline \multirow{2}{*}{ Elbow } & 0 & 58 & 96.7 & 90 & 97.8 & 60 & 100 & \multirow{2}{*}{$p>0.05$} \\
\hline & I & 2 & 3.3 & 2 & 2.2 & 0 & 0 & \\
\hline \multirow{3}{*}{ Wrist } & 0 & 33 & 76.7 & 43 & 93.5 & 30 & 100 & \multirow{3}{*}{$\mathrm{p}<0.001$} \\
\hline & I & 3 & 10 & 3 & 6.5 & 0 & 0 & \\
\hline & II & 4 & 13.3 & 0 & 0 & 0 & 0 & \\
\hline \multirow{3}{*}{ MCPS } & 0 & 42 & 70 & 84 & 91.4 & 60 & 100 & \multirow{3}{*}{$\mathrm{p}<0.001$} \\
\hline & I & 14 & 23.3 & 4 & 4.3 & 0 & 0 & \\
\hline & II & 4 & 6.7 & 4 & 4.3 & 0 & 0 & \\
\hline \multirow{4}{*}{ PIPS } & 0 & 36 & 60 & 84 & 91.4 & 60 & 100 & \multirow{4}{*}{$\mathrm{p}<0.01$} \\
\hline & I & 12 & 20 & 4 & 4.3 & 0 & 0 & \\
\hline & II & 0 & 0 & 4 & 4.3 & 0 & 0 & \\
\hline & IV & 12 & 20 & 0 & 0 & 0 & 0 & \\
\hline \multirow{4}{*}{ DIPS } & 0 & 22 & 36.7 & 86 & 93.4 & 60 & 100 & \\
\hline & $\mathrm{I}$ & 18 & 30 & 4 & 4.4 & 0 & 0 & $n<0 \Omega 01$ \\
\hline & II & 2 & 3.3 & 2 & 2.2 & 0 & 0 & $p-0.001$ \\
\hline & IV & 18 & 30 & 0 & 0 & 0 & 0 & \\
\hline Hinc & 0 & 58 & 96.7 & 92 & 100 & 60 & 100 & $n>005$ \\
\hline 111ps & I & 2 & 3.3 & 0 & 0 & 0 & 0 & $p-0.03$ \\
\hline & 0 & 28 & 46.6 & 68 & 47 & 52 & 86.6 & \\
\hline & I & 12 & 20 & 12 & 13 & 4 & 6.7 & מחمח \\
\hline Knees & II & 16 & 26.7 & 6 & 6.5 & 4 & 6.7 & $p<0.001$ \\
\hline & III & 4 & 6.7 & 6 & 6.5 & 0 & 0 & \\
\hline & 0 & 52 & 87.7 & 92 & 100 & 60 & 100 & \\
\hline Ankle & I & 6 & 10 & 0 & 0 & 0 & 0 & $\mathrm{p}<0.05$ \\
\hline & II & 2 & 3.3 & 0 & 0 & 0 & 0 & \\
\hline Subtalar & 0 & 56 & 93.3 & 92 & 100 & 60 & 100 & $P>005$ \\
\hline Juvtalal & I & 4 & 6.7 & 0 & 0 & 0 & 0 & $P>0.05$ \\
\hline & 0 & 44 & 73.4 & 88 & 95.7 & 60 & 100 & \\
\hline MTPS & I & 8 & 13.3 & 4 & 4.3 & 0 & 0 & $\mathrm{p}<0.001$ \\
\hline & II & 8 & 13.3 & 0 & 0 & 0 & 0 & \\
\hline
\end{tabular}




\section{Orthopedics and Rheumatology Open Access Journal}

Table 2: The radiological findings for cases, contacts and controls according to Larsen et al. [9].

\begin{tabular}{|c|c|c|c|c|c|c|c|c|}
\hline & & \multicolumn{2}{|c|}{ Cases } & \multicolumn{2}{|c|}{ Contact } & \multicolumn{2}{|c|}{ Control } & \\
\hline & & No. & $\%$ & No. & $\%$ & No. & $\%$ & \\
\hline \multirow[t]{5}{*}{ Hand } & Grade 0 & 26 & 43.4 & 90 & 95.7 & 60 & 100 & $<0.0001$ \\
\hline & Grade I & 14 & 23.3 & 0 & 0 & 0 & 0 & \\
\hline & Grade II & 8 & 13.3 & 2 & 15.2 & 0 & 0 & \\
\hline & Grade IV & 6 & 10 & 0 & 0 & 0 & 0 & \\
\hline & Grade V & 6 & 10 & 0 & 0 & 0 & 0 & \\
\hline \multirow[t]{3}{*}{ Elbow } & Grade 0 & 48 & 80 & 92 & 100 & 60 & 100 & $<0.001$ \\
\hline & Grade I & 10 & 16.7 & 0 & 0 & 0 & 0 & \\
\hline & Grade V & 2 & 3.3 & 0 & 0 & 0 & 0 & \\
\hline \multirow[t]{5}{*}{ Knee } & Grade 0 & 26 & 43.4 & 78 & 84.8 & 52 & 86.6 & $<0.001$ \\
\hline & Grade I & 18 & 30 & 8 & 8.7 & 4 & 6.7 & \\
\hline & Grade II & 8 & 13.3 & 4 & 4.3 & 4 & 6.7 & \\
\hline & GradeIV & 8 & 13.3 & 2 & 2.2 & 0 & 0 & \\
\hline & Grade V & 0 & 0 & 0 & 0 & 0 & 0 & \\
\hline \multirow[t]{5}{*}{ Ankles } & Grade 0 & 38 & 63.3 & 80 & 93.5 & 60 & 100 & $<0.001$ \\
\hline & Grade I & 8 & 13.3 & 6 & 6.5 & 0 & 0 & \\
\hline & Grade II & 10 & 16.7 & 6 & 0 & 0 & 0 & \\
\hline & GradeIV & 0 & 0 & 0 & 0 & 0 & 0 & \\
\hline & Grade V & 4 & 6.7 & 0 & 0 & 0 & 0 & \\
\hline \multirow[t]{3}{*}{ Spine } & Grade 0 & 36 & 60 & 80 & 87 & 52 & 86.6 & $<0.01$ \\
\hline & Grade I & 14 & 23.3 & 6 & 6.5 & 8 & 13.4 & \\
\hline & Grade II & 10 & 16.7 & 6 & 6.5 & 0 & 0 & \\
\hline
\end{tabular}

Table 3: The serum level of APGL-1 (IgM) antibodies in the studied groups

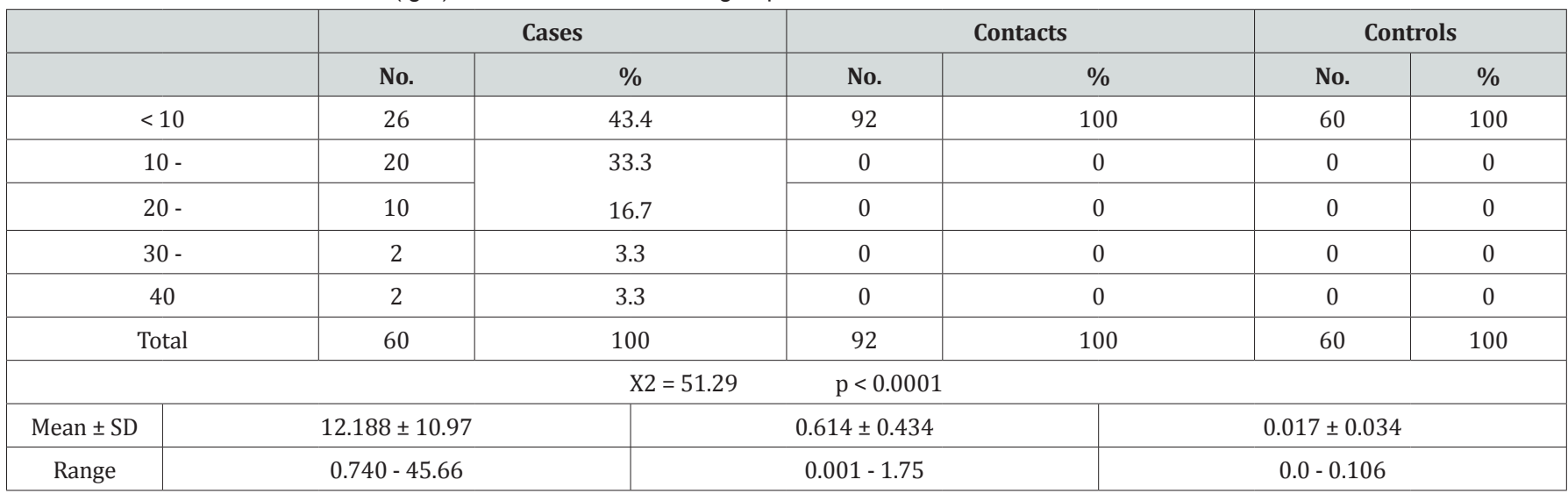

Table 4: Shows the serum level of APGL 1 ( $\lg G$ ) antibodies in the studied groups.

\begin{tabular}{|c|c|c|c|c|c|c|}
\hline & Cases & Contacts & & controls & & \\
\hline No. & & $\%$ & No. & $\%$ & No. & $\%$ \\
\hline 42 & $<1$ & 70 & 92 & 100 & 60 & 100 \\
\hline 12 & $1-$ & 20 & 0 & 0 & 0 & 0 \\
\hline 4 & $2-$ & 6.7 & 0 & 0 & 0 & 0 \\
\hline 2 & $3-$ & 3.3 & 0 & 0 & 0 & 0 \\
\hline 60 & Total & 100 & 92 & 100 & 60 & 100 \\
\hline \multicolumn{7}{|c|}{$X 2=51.29$} \\
\hline $0.918 \pm 0.714$ & \multicolumn{2}{|c|}{ Mean \pm SD } & \multicolumn{2}{|c|}{$0.240 \pm 0.136$} & \multicolumn{2}{|c|}{$0.076 \pm 0.052$} \\
\hline $0.420-3.100$ & Range & & \multicolumn{2}{|c|}{$0.017-0.498$} & \multicolumn{2}{|c|}{$0.009-0.195$} \\
\hline
\end{tabular}




\section{Orthopedics and Rheumatology Open Access Journal}

Table 2 showed that the radiological changes of the hand joints were significantly higher among the cases than the other two groups $(\mathrm{P}<0.0001)$. Also the radiological changes of elbows, knees, ankle, and spine were significantly higher among cases than in other two groups where $\mathrm{P}<0.001$. Table 3 showed that the mean serum level of APGLI (IgM) antibodies was significantly high in cases and their household contacts than in control where $(\mathrm{p}<0.0001)$, Also Table 4 showed that the serum level of APGLI (IgG) antibodies was also significantly higher in cases and their household contacts than in control groups where $(\mathrm{P}<0.0001)$. Table 5 showed that the hypopigmented, hypoesthetic skin rashes were detected more among case than in contacts and control groups $\mathrm{P}<0.001$.

Table 5: Skin manifestations of the studied groups.

\begin{tabular}{|c|c|c|c|c|c|c|c|}
\hline & \multicolumn{2}{|c|}{ Cases affected } & \multicolumn{2}{|c|}{ Contacts affected } & \multicolumn{2}{|c|}{ Controls affected } & \\
\hline & No. & $\%$ & No. & $\%$ & No. & $\%$ & \\
\hline Hypopigmentation & 28 & 46.7 & 4 & 4.3 & 0 & 0 & $<0.001$ \\
\hline Hyperpigmentation & 18 & 30 & 6 & 6.5 & 0 & 0 & $<0.01$ \\
\hline Ulcers & 10 & 16.7 & 2 & 2.2 & 0 & 0 & $<0.01$ \\
\hline Nodules & 8 & 13.3 & 6 & 6.5 & 0 & 0 & $>0.05$ \\
\hline Raynaude's & 10 & 16.7 & 12 & 13 & 0 & 0 & $>0.05$ \\
\hline Urticaria & 4 & 6.7 & 8 & 8.7 & 0 & 0 & $>0.05$ \\
\hline
\end{tabular}

Hyper pigmentation and ulcers were significantly more frequent in cases than in the other two groups $\mathrm{P}<0.01$. However there was no significant difference between all of the studied

groups regarding nodules, Raynaud's and urticarial rashes. The erythrocyte sedimentation rate was significantly higher in cases than in contacts and least was among controls $\mathrm{P}<0.0001$ (Table 6).

Table 6: ESR of the studied groups.

\begin{tabular}{|c|c|c|c|c|c|c|}
\hline & \multicolumn{2}{|c|}{ Cases } & \multicolumn{2}{|c|}{ Contacts } & \multicolumn{2}{|c|}{ Controls } \\
\hline & No. & $\%$ & No. & $\%$ & No. & $\%$ \\
\hline$<20$ & 6 & 20 & 26 & 56.5 & 28 & 93.3 \\
\hline $20-$ & 14 & 46.7 & 19 & 41.3 & 2 & 6.7 \\
\hline $40-$ & 6 & 20 & 1 & 2.2 & 0 & 0 \\
\hline $60-$ & 3 & 10 & 0 & 0 & 0 & 0 \\
\hline $80+$ & 1 & 3.3 & 0 & 0 & 0 & 0 \\
\hline Total & 30 & 100 & 46 & 100 & 30 & 100 \\
\hline \multicolumn{7}{|c|}{$\mathrm{X} 2=44.84$} \\
\hline Mean \pm SD & $35.47 \pm 18.52$ & & $18.28 \pm 10.62$ & & $9.20 \pm 6.02$ & \\
\hline
\end{tabular}

\section{Discussion}

Arthritis is one of the most common leprotic manifestations which may simulate rheumatoid arthritis as stated by Hanafy, et al. [13]. They found that the most commonly involved joints in leprotic arthritis were: elbow (84\%), wrist (80\%), MCP (80\%), PIP (80\%), DIP (85\%), knee (66\%), ankle (72\%), TMJ (66\%), and MTP (60\%). However Karat, et al. [6], stated that a true arthritis may occur particularly in erythematic nodosum leprosum (ENL) which is a reactional state in lepromatous leprosy. The musculoskeletal manifestations may be an important cause of continuing morbidity in leprosy [14]. During the past decade, serological tests for detection of anti-mycobacterium leprae antibodies have been developed, among them, the enzyme-linked immunosorbent assay (ELIZA) using the purified phenolic glycolipid-I (PGL-I) from the cell wall as a mycobacterium leprae specific antigen has proved to be potentially useful for the serological diagnosis of leprosy patients, household contacts and normal individuals due to its simplicity, sensitivity as well as its capability of handling large numbers of sera simultaneously [15].
Buchanan et al, observed that the elevated levels of antiphenolic glycolipid I (APGL-I) preceded the clinical diagnosis in most cases, and reported the development of leprosy in two out of eighteen household contacts with persistent seropositivity, and found no cases among 94 household contacts who were persistently seronegative or only transiently positive followed for 30 months [15]. Early diagnosis and chemotherapeutic intervention is the most essential prerequisite for decreasing deformities associated with leprosy [16].

Initiation of the antibody responses generally requires a much lower antigenic load and, therefore, should precede the clinical diagnosis. Thus antibodies, particularly IgM and IgG isotypes, should aid in the early diagnosis of leprosy infection [17]. APGL-I (IgM) was significantly higher among cases than household contacts and control group, $(\mathrm{p}<0.0001$. Also it was higher among household contacts than controls $(\mathrm{p}<0.0002$. Our findings were consistent with those of some other studies $[18,19]$.

APGL-I (IgG) was significantly higher among cases than household contacts and control group where $\mathrm{p}<0.0001$. Also it 


\section{Orthopedics and Rheumatology Open Access Journal}

was higher among household contacts than control group where $\mathrm{p}$ $<0.0002$ in consistent with studies that done by Hanafy, et al. [13]. Erythrocyte sedimentation rate (ESR) (Figure 3) was significantly higher among twenty eight out of sixty leprotic patients and thirty eight out of ninety two household contacts compared to the control group and this is consistent with the previous study that done by Hanafy, et al. [13].

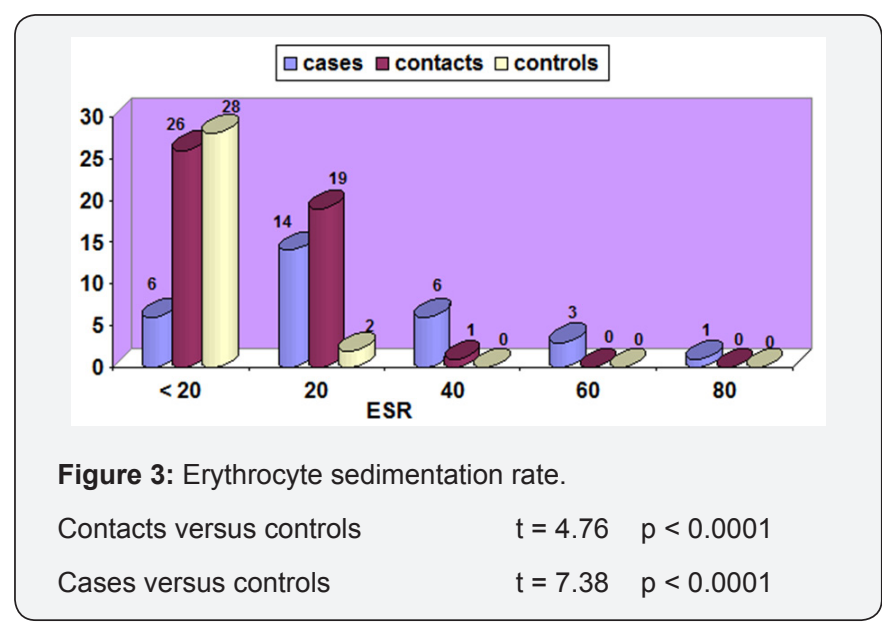

The serological data of our study revealed a clear age-related correlation with the serum level of anti PGL-I (IgM) among the household contacts only, as agreed Fine, et al. [20]. Overall IgM and IgG levels have been reported to increase during youth and to decease subsequently with increasing age [21]. Several circumstance my lead to such an age trend. Most likely a peak in the seropositivity rates in the young group reflects a high exposure to infection during this age or the foregoing period [20]. In the present study there was no detected difference in seropositivity rates among males and females, in contrast to the population - based study in Malawi that was done by Fine, et al. [20].

Correlating the mean serum level of anti-PGL-I (IgM, IgG) with ESR and latex test for rheumatoid factor (RF) for all the studied groups, revealed that anti-PGL-I (IgM, IgG) were significantly correlated to ESR among the household contacts only and significantly correlated to latex test for RF in both leprotic patients and household contacts. The elevation of ESR can be explained on the basis of stimulation of the immune response by the infection with mycobacterium leprae resulting in hypergama-globulinaemia [22] or it may represent Arthur phenomena [23]. So, ESR may be considered as a parameter for disease activity in acute or sub-acute leprotic infection.

In the present study, the rheumatological examination showed that the most commonly involved joints among the leprotic patients as well as household contacts were: the distal interphalangeal (DIP) 63.3\%, metacarpophalangeal (MCP) 30\% metatarsophalangeal $26.6 \%$ followed by wrist $23.3 \%$, ankle $13.3 \%$ and acromioclavicular joint $10 \%$, but the arthritis was significantly higher in leprotic patients than household contacts according to the (SS index) where p value was $<0.01,<0.05,<0.05,<0.01,<0.05,<0.05$ respectively.
This is consistent with the previous study by Hanafy, et al. [13] who reported the same findings with exception of the elbow joint which was involved only in $3.3 \%$ in our study compared to $84 \%$ in the study which was done by Hanafy, et al. [13]. Among the household contacts, the most commonly involved joint was the knee joint $26 \%$ compared to $53.4 \%$ among the leprotic patients ( $p>0.05$ ). Also they reported that the knee joint was involved in $72 \%$ among leprotic patients.

Our study highlights that a symmetrical polyarthritis may be a facet of the leprosy infection. As regards the enthesopathic lesions, it was found that the supraspinatus enthesis was significantly involved in leprotic patients than household contacts and control group. lateral epichondylitis was the most common involved enthesis. This could imply that the enthesopathy may be one of the early rheumatic manifestations of leprosy and therefore may considered as a reactive arthropathy for a well-known pathogen as reported by Inderpal and Surrinder [23].

Both anti -PGL-I (IgM) and (IgG) was significantly correlated to the enthesopathy among the household contacts only. As regards skin manifestations, it was found that hypopigmentation and hyperpigmentation were detected more among the leprotic patients than the household contacts and control group with a very highly significant difference $\mathrm{p}<0.001$ and $<0.01$ respectively. This may be due to the fact that melanocytes like nerves are derived from the neural crest and there is a special affinity between mycobacterium leprae and all the neural crest tissues further the role of melanin in the metabolism of mycobacterium leprae [24].

Radiological examination for all the studied groups showed some abnormalities in both upper and lower limbs among both leprotic patients and their household contacts as follows: X-ray hand of leprotic patients showed soft tissue swelling (23.3\%), osteoporosis which may be localized (juxta - articular) or generalized $(13.3 \%)$, periosteitis, joint space narrowing and bone absorption (10\%), deformities and ankylosis (10\%). This is consistent with the study done by Hanafy, et al. [13] who found the same changes, while the only changes which could be detected among the household contacts was juxta-articular osteoporosis (15.2\%). Dinarello [25] stated that IL-I, IL-6 and TNF- $a$ are a major cytokines produced by macrophages of leprosy and these cytokines stimulate immunological inflammatory reactions. In contrast, IL10 inhibits macrophage functions and influences the subsequent macrophage/T cell interaction [26].

TNF-a enhanced the production of reactive nitrogen oxide and inhibits mycobacterial growth in human macrophages. ILI, stimulates the liver cells to secrete the acute phase reactants [27]. TNFa together with IL-I produce juxta articular osteoporosis [28]. Waters, et al. [29] reported that X-ray hand of the untreated lepromatous leprosy patients may reveal asymmetrical phalangeal cysts, presumed to be due to lepromatous infiltration. Inderpal and Surrender stated that osteoporosis around the affected joints, at times, was more than what could be expected from disease and 
reported a reduction in transverse trabeculae in the subcortical layer and a diminution of longitudinal layers of trabeculae in the cortex [18].

Plain X-ray elbows showed Charcot's joint in two leprotic patient (3.3\%) and soft tissue swelling in 10 patients (16.7\%). No radiological changes could be detected among the elbows of household contacts. Radiological examination of the knees showed soft tissue swelling in 18 leprotic patients (30\%) versus 8 household contacts $8.7 \%$ ), osteoporosis in 8 leprotic patients $13.3 \%$ ) versus 4 household contacts $4.3 \%$ ), periosteitis and joint space narrowing in 8 leprotic patients $13.3 \%$ ) versus 2 household contacts $2.2 \%$ ). X-ray ankle showed soft tissue swelling in 8 leprotic patients $13.3 \%$ ) versus 6 household contacts (6.5\%), osteoporosis in 10 leprotic patients (16.7\%) versus 10 household contacts $(10.9 \%)$, bone absorption and deformities in 4 leprotic patients $(6.7 \%)$ only. Hanafy et al reported that in some long standing cases whether treated or untreated, there is absorption of the terminal phalanges and typical penciling of the heads and shafts of meatarsal bones. All of these radiological changes were significantly higher in leprotic patients than household contacts and control groups $(\mathrm{p}<$ $0.0001, \mathrm{p}<0.001$ ) [13].

In the present study, the severity of arthritis was significantly correlated to latex test for RF among the leprotic patients only. Simulating what happens in rheumatoid arthritis, Cats and Hazevoet observed that patients with a positive test for RF in the blood have more sever clinical disease and complications than do seronegative patients [28]. Allen, et al. [30] observed that increased levels of IgG $\mathrm{RF}$ have been associated with a high frequency of subcutaneous nodules, vasculitis, elevated ESR, decreased compliment levels and increased numbers of joint involvement [31,32].

Correlating ESR to the other studied variables, it was found that ESR was significantly correlated to both RF and the enthesopathy among the household contacts only. Finally we can conclude that the radiological changes started as early as a soft tissue swelling and osteoporosis with or without signs of arthritis in household contacts, and proved that the radiological changes is one of the suggestive diagnostic manifestations of musculoskeletal leprosy which should be confirmed by serological investigation (APGL-I) Lastly we can suggest the following criteria for early prediction and diagnosis of leprotic arthropathy which might be:

I. Positive APGL-I $(\operatorname{IgM}>0.085, \operatorname{IgG}>0.0180)$.

II. High enthesopathy index $>10$.

III. Skin manifestations (hypo or hyper pigmented patches).

IV. Loss of hair especially eye brows.

V. Arthralgia and / or arthritis in attacks: RA like, or monoarticular.

VI. Peripheral nerve thickening
VII. Radiological changes wither early as: -

A. Soft tissue swelling

B. Osteoporosis

C. Acroosteolysis

Or late as:

i. joint space narrowing

ii. Acroosteolysis

iii. Arthritis multilans

iv. Deformities and ankylosis

\section{References}

1. Jopling WH (1986) Borderline leprosy maintaining a polyneuritic form for eight years: a case report. Transaction of the Royal society of Tropical Medicine and Hygiene 50: 478-480.

2. Buchanan T, Dissanyake S, Young DB, Miller RA (1983) Evaluation of the significance of antibodies to phenolic glycolipid - I of mycobacterium leprae in leprosy patients and their household contacts.(Abstract). Int J Lepr 51: 658-659.

3. Cho SN, Fujiwara T, Hunter SW (1984) Use of artificial antigen containing the 3, 6-di-O-methyl-â-D-Glycopyranosyl epitope for the sero diagnosis of leprosy. J Inf Dis 150: 311-322.

4. Road H (1991) Leprosy stigma. Lepr Rev 62: 1-12.

5. Jopling, WH, Mc Dougall AC (1988) Handbook of leprosy, 4th edition, Heinemann Professional publishing, London, UK.

6. Karat ABA, Karat S, Job CK, Furness MA (1967) Acute exudative arthritis in leprosy: a rheumatoid-like syndrome in association with Erythema nodosum leprosum. Br Med J 3: 770-772.

7. Lela RC, Sainani GS, Sharma KD (19685) Leprosy presenting as rheumatoid arthritis. Assoc Physicians India 13: 275-277.

8. Modlin RL, Melan Con-Kaplan J, Young SMM (1988) Learning from lesions: Pattern of tissue inflammation in leprosy. Proc Natl Acad Sci USA 85: 1213-1217.

9. Walke DJ, Griffith ID (1986) HLA associations are with severe rheumatoid arthritis. Dis Markers 4: 121-132.

10. Ritchie DM, Boylle JA, Mchlnnes JM, Jasani MK, Dalakos TG, et al. (1968) Clinical studies with an articular index for assessment of joint tenderness in patients with rheumatoid arthritis. Qtrly Med 37: 393406.

11. Larsen A Dale K, Eek M (1977) Radiographic evaluation of rheumatoid arthritis and related conditions by standard reference films. Acta Radiol Diagnosis 18: 481-491.

12. Kazda J, El-Tayeb SH, Abdel-Fattah AM (1993) Study of some immunological changes in active and treated leprotic patients. MD Thesis. Al-Azhar University.

13. Hanafy MI, Bassiouni MH, Abdel All H (1982) Leprotic arthropathy. M.D. thesis, Al-Azhar University.

14. Albert DA, Weiseman MH, Kaplan R (1980) The rheumatic manifestations of leprosy. Medicine (baltimore) 59: 442-448.

15. Buchanan T, Dissanyake S, Young DB, Miller RA (1983) Evaluation of the significance of antibodies to phenolic glycolipid - I of mycobacterium 
leprae in leprosy patients and their household contacts.(Abstract). Int J Lepr 51: 658-659.

16. Rabia H, Sarwat J, Arnauaz K, Fatma F, Rumina H (1990) Quantitization of Img antibodies to M. leprae synthic disaccharide can predict early bacterial multiplication in leprosy. Int J Lepr 58(3): 491-502.

17. Maurice JL, Mesfing H, Ernest S (1991) The value of IgM antibodies, to PG-I in diagnosis of leprosy. Int J Lepr 59(3): 432-440.

18. Douglas JT, Celona RV, Abalos RM, Madarang MG, Fajardo T (1987) reactivity and early detection of leprosy among contacts of lepromatous leprosy in Cebu. Int. J Lepr 55(4): 718-721.

19. Chanteau S, Cartel JL, Roux R, Bach MA (1987) Comparison of synthetic antigen for detecting antibodies to ohenolic glycolipid in patients with leprosy and their household contacts. Infect. Dis 157(4): 770 -776.

20. Fine LEM, Ponnighous JM, Burgess P, Klarkson JA, Draper CC (1988) Serepidemiological studies of leprosy in northern Malawi based on an enzyme - linked immunosorbent assay using synthetic glycoconjugate antigen. Int J Lepr 56(2): 243-254.

21. Buckley C E, Dorsey FC (1970) The effect of ageing on human serum immunoglobulin concertrations. J Immunol 105: 964-972.

22. Bonomo L, Pinto L, Dammaco, F, Berbieri, G (1983) Thymoglobulin antibodies in leprosy. Lancet 2: 807-809.

23. Inderpal S, Surrindes K (1994) Arthritis in leprosy: Clinical, laboratory and Radiological assessments. Int J Lepr 62(3): 428-432.
24. Job CK, Nayart A, Narayan, JS (1972) Electron microscope study of hyperpigmented lesions in leprosy. Br J Dermatol 87: 200-212.

25. Dinarello CA (1989) Interleukin -I and its biologically related cytokines. Adv Immunol 44: 153-205.

26. Fioentino DF, Zlotinic A, Vieira O, Mosmann TR, Moore KW, et al. (1991) IL-10 acts on the antigen presenting cell to inhibit cytokine production by Th. 1 cells Immunol 146: 3444-3451.

27. Pettipher ER, Higgs GA, Henderson B (1986) IL-I induces leukocyte infiltration and cartilage degeneration in the synovial joint. Proc Nat Acad Sci USA 83(22): 8749-8753.

28. Bertolini DR, Nedwin GE, Smith DD, Mundy GR (1986) Stimulation of bone resorption and inhibition of bone formation by human tumor necrosis factors. Nature 319: 516-527.

29. Waters MFR (1984) Oxford text book of Medicine. Oxford university press. Inc. New York. USA.

30. Allen C, Elson C, Scott DGI, Bucknall RC (1981) IgG antiglobulins in rheumatoid arthritis and other arthritides: Relationship with clinical features and other parameters. Ann Rheum Dis 40: 127-129.

31. Hasan R, Hazel MD, Thomas C, Rabia H (1989) Quantities antibody ELISA for leprosy. Int J Lepr 57(4): 766-775.

32. Cats A, Hazevoet HM (1970) Significant of positive tests for rheumatoid factor in the prognosis of rheumatoid arthritis. Ann Rheum Dis 29 254-260.

\section{Your next submission with Juniper Publishers} will reach you the below assets

- Quality Editorial service

- Swift Peer Review

- Reprints availability

- E-prints Service

- Manuscript Podcast for convenient understanding

- Global attainment for your research

- Manuscript accessibility in different formats

( Pdf, E-pub, Full Text, Audio)

- Unceasing customer service

Track the below URL for one-step submission https://juniperpublishers.com/online-submission.php 